\title{
Bilingual Experience in the Hungarian and German Immigrant Communities of the San Francisco Bay Area
}

\author{
Gergely Tóth, University of California, Berkeley
}

Abstract: Studies on the interaction of languages are gaining importance in today's world, characterized by accelerated migration and increasing cultural exchange. Unlike most research in this field, which concentrate on one embedded language against a matrix language, this fieldwork-based study examines the linguistic life in two immigrant populations, Hungarian and German, against the background of English. The primary focus of this article is the description of the bilingual and bicultural experience of the two groups. The discussion of language and identity will take a central place in the paper, and diglossia, bilingualism, loyalty, and language as social behavior will also be touched upon (section 4). This is complemented by a socio-historical portrayal of these speech communities of San Francisco, set forth in the preceding section 3. Section 5 provides an outline of the informant sets, spanning three generations in each linguistic cohort, and illustrates the subjects' attitude towards maintenance. The final, sixth section offers qualitative and quantitative comparative statements about the results of linguistic interference and the ongoing attrition process, thus contributing to our understanding of contact linguistic mechanisms, and shedding light on specific grammatical and lexical features that are most prone to attritional forces.

Keywords: Hungarian and German immigration history, diaspora, linguistic interference, attrition, maintenance, San Francisco, California

Biography: Gergely Tóth studied at Eötvös Lóránd University (ELTE) in Budapest and at the University of Heidelberg, and received his Ph.D. in Germanic linguistics from the University of California, Berkeley where he served as lecturer in Hungarian and German until 2012. His interests include sociolinguistics, especially language and culture maintenance, attrition and loss, dialectology, semiotics, historical linguistics, and immigration history. For the latter, he has conducted extensive fieldwork research in Hungarian communities throughout the United States. His book Linguistic Interference and First Language Attrition: German and Hungarian in the San Francisco Bay Area appeared in 2007.

Throughout history there have been few languages in the world that haven't been exposed to some outside influence, whether peaceful and gradual or forced and radical in character. Language contact research, accordingly, has long traditions that date back into the nineteenth century and to the theoretical foundations laid by Neogrammarians such as Hugo Schuchardt (1883) and Hermann Paul (1886), were interested in historical contacts. Uriel Weinreich's groundbreaking work, which focuses on immigrant languages, Languages in Contact, and his efforts in organizing immigrant language research have had great influence on contact linguistics and delivered the current definition of linguistic interference as "deviation from the norms of either language which occurs in the speech of bilinguals" (Weinreich 1). Recent contact linguistic investigation encompasses complex approaches that involve several related fields, ranging from sociology, psychology, anthropology, culture and literature, education, and neurology to multiple-language acquisition and pidgin and Creole linguistics. This variety and combination of interests can make contact linguistic discussions very suitable Cultural Studies topics.

Due to the accelerated migration processes and to rapid political and social changes of modern times, cultural and linguistic interaction of diverse populations has significantly increased in the past century and a half. Consequently, the role of disciplines that are interested in the effects of these large-scale changes in general, and contact linguistics in particular, has become more and more vital. One of the consequences of global movements which have special relevance for the researcher is that data resulting from contact situations are practically infinite, as mechanisms of social, political, economic, cultural, linguistic, and situational interference have been increasingly active and productive. These data also ensure a continuing flow of inspiration, research topics, and perspectives for researchers, both linguists and scholars from 
Tóth, Gergely. "Bilingual Experience in the Hungarian and German Immigrant Communities of the San Francisco Bay Area." AHEA: E-journal of the American Hungarian Educators Association, Volume 5 (2012): http://ahea.net/e-journal/volume-5-2012

various other fields, policy makers, and last but not least, for the field of Cultural Studies. It is thus a real necessity to conduct more research on cultures and languages in contact (cf. Gal 1979, or Langman 1997).

The goal of this article is to provide the reader with a description of the bilingual and bicultural experience of the San Francisco Bay Area Hungarian and German communities, in conjunction with highlighting some of the linguistic phenomena which stem from language contact. More importantly, issues of a concept, central to Cultural Studies concerns today, will be analyzed: those of identity, performed through often rudimentary language competence. I will also investigate whether, in the light of the attested accelerated linguistic demise, long-term language retention is a plausible prospect of expatriate speech communities whose speakers are undergoing a change from their native languages to English. The contact linguistic data of this study come from the rendition into Hungarian and German of the 25 English sentences of the Bay Area German Fieldwork Project (Rauch et al. 1988), provided by twenty German and twenty Hungarian speakers in the course of a contrastive fieldwork project in 2004. I also collected linguistic and biographic-sociolinguistic questionnaires and conducted personal observation; my results are detailed in the second half of the paper. I compared the informants' linguistic output, including all identified nongrammatical forms and constructions, with the standard varieties of German and Hungarian. What characterizes my survey is that while contact linguistic research typically contrasts one language with another, I undertook the examination of two languages against a third, in order to see how these two nonrelated languages react to the pressures of the surrounding English. Additionally, I placed emphasis on the division of first- vs. second- and third-generational data (data sets I and II, respectively), in an effort to separate the results with regards to their origins in a deteriorated, crumbling native language of first generational immigrants, or an imperfect, so-called heritage language of speakers of the second and third generations.

One of the reasons for conducting such a survey is that during my encounters with the members of the two speech communities, obvious contact linguistic phenomena, occurring in the shadow of language shift, always fascinated me. My pool of unsolicited and volunteer information provides intriguing examples ranging from the common to the entertaining or even the grotesque, as in the following examples. (a) is a line from a letter in German, displaying gender insecurity and orthographic deviations (feminine for a masculine addressee and [f] in place of [v]), and (b) is a loan-idiom sample, the mirror translation of an English phrase which doesn't make sense in German.

(a)

Liebe G.T., fielen Tank ...

dear.fem G.T.masc, many thank ...

(b)

L. ist keine leichte Person, Freund mit zu machen.

L. is no easy person, friend with to make.inf

Sample (c) is an email paragraph in Hungarian that bears a typical sign of attrition, viz., the transformation of the linguistic structure into a more analytic state, displaying deficient case marking and orthographic separation of agglutinative nominal suffixes. Finally, (d) exemplifies the entertaining or absurd aspect of some language contact results. The literal translation of the sentence is I'm sorry, I chopped/slashed them off (in lieu of I cut them off [in a line]).

(c)

Szia G.,

A nevem R. R. En Kanadaba szulettem, 34 eves vagyok es meg nincs csaladom. Francia iskolaba tanultam amikor Montreal ba laktam, es kaptam Ph.D. biochemistry ba.

Hello G., the my-name-is R.R. I in-Canada I-was-born, 34 years-old I-am and yet I-have-no my-family. French in-school Istudied when Montreal in I-lived, and I-received Ph.D. biochemistry in. 
Tóth, Gergely. "Bilingual Experience in the Hungarian and German Immigrant Communities of the San Francisco Bay Area." AHEA: E-journal of the American Hungarian Educators Association, Volume 5 (2012): http://ahea.net/e-journal/volume-5-2012

(d)

Bocsánat, levágtam öket.

sorry, I-chopped-off them.acc

The following sections describe the two investigated speech communities and their bilingualbicultural experience. As Dell Hymes states, "speech community is a necessary, primary term in that it postulates the basis of description as a social, rather than a linguistic, entity. One starts with a social group and considers all the linguistic varieties present in it, rather than starting with any one particular, dominant variety" (Hymes 54). Indeed, my aim, beyond a socio-historical delineation, is to provide a tentative linguistic profile of these communities from which my informants come. Such an introduction of a speech community should include, in the sense of John Gumperz' 'interpretive' or 'interactional sociolinguistics', an integration of the descriptive dimensions language, interaction structures, institutional organization, and the investigator's knowledge about social groups. A sociolinguistic or ethnographically-oriented approach is also necessary because the term 'speech community' entails shared rules for the conduct and interpretation of speech, and for the comprehension of at least one linguistic variety. Or, as Georges Lüdi puts it, "a common language of origin alone is not sufficient to create anything like a 'language community' ... but that other social variables determine the (...) social network" (Lüdi 130). In addition, this kind of examination of institutions also provides a solid Cultural Studies basis for contact linguistic investigations.

The Hungarian population of the United States, since its first sizeable appearance in the country around 1880, has for a long time concentrated around the industrial areas of the East Coast and the Great Lakes. A significant constituency in the West Coast started to form only half a century later, but particularly after 1956, with Los Angeles as the historical center. Thus, the Hungarian community of the Bay Area is relatively young. The 2000 Census recorded a total number of 90,000 California residents with "first Hungarian ancestry." With regards to the San Francisco Bay Area, the Census shows approximately 12,000 Hungarians. The central address list, maintained by community leaders, contains approximately 1,400 addresses of individuals or families who are more or less actively involved in ethnic community life. The active-inactive distinction is crucial from the point of view of participation in, and thus the support and survival of, ethnic institutions. The number of "non-active" Hungarians is, similarly to other ethnic groups, obviously larger. This latter part presumably consists of speakers with a lower degree of ethnic and linguistic loyalty, such as most newly arrived professionals in Silicon Valley who seem to belong to this segment.

Hungarians arrived in America in three major waves. The first group, the so-called öregamerikások or 'old Americans', as later immigration waves refer to these, were part of the largest influx between ca. 1880 and 1915 when approximately two million Hungarians from all across the Carpathian Basin entered. However, because of the distances, only a few actually made it to the West Coast. The second considerable wave included mostly displaced persons (called $D P S$ ) fleeing Hungary from the Soviet troops at the end of World War II, along with some survivors of the Holocaust. Those who ended up in the Western United States started to arrive in this area after 1949. To be sure, there was also a group of Jewish Hungarians, mostly artists and scientists, who left Europe in the late thirties and early forties because of Nazism. Several of them, for example, went to Hollywood and became important, not as much in numbers as in cultural influence. Then the third large wave brought over refugees of another communist invasion, following the freedom fight of 1956. At that time, some 40,000 Hungarians were admitted in the US. Since the late 1950s, immigration has been sporadic, on an individual basis, and, past the late eighties, for economic reasons. A fundamental difference between these Hungarian and German immigrant groups is the reasons for relocation. Most Hungarians currently active in ethnic life had to leave for political reasons, while most Germans arrived here hoping for employment opportunities. Also, both the Hungarian and German entities of the Bay Area have a low degree of community continuity. Most current speakers are not descendants of original local settlers. The sole exception in this survey is an öregamerikás Hungarian consultant whose parents arrived in the Bay Area around 1910.

The local Hungarian population has never had a compact "neighborhood." It lived scattered around the city, this resulting in a group dynamics which differed from the major East Coast communities such as Cleveland's East and West Sides, Lackawanna and Tonawanda in Buffalo, Detroit's Delray district, 
Tóth, Gergely. "Bilingual Experience in the Hungarian and German Immigrant Communities of the San Francisco Bay Area." AHEA: E-journal of the American Hungarian Educators Association, Volume 5 (2012): http://ahea.net/e-journal/volume-5-2012

Somerset Street in New Brunswick, NJ, or the Bloor Street area in Toronto. The first attestations of Hungarian social organization in San Francisco that I came across are the September $25^{\text {th }}$, and October $23^{\text {rd }}$, 1881 issues of Vasárnapi Újság (Sunday Paper) of Hungary; they reported that the Széchenyi brothers, Imre and Géza, and Count Andrássy were made honorary members of the San Francisco Hungarian Benevolent Club - the young nobles were touring and studying the USA (information courtesy of Susan Glanz). Also, in Langley's San Francisco, California General and Business Directory for 1890, the entry Hungarian Social and Mutual Aid Society of the Pacific Coast is to be found. Other organizations followed, most notably the Dalárda (Singing Circle) that started in the 1920's as a men's choir and later amalgamated with the Women's Guild. The Pannonia Sport Club, which cared for some of the Hungarian refugee athletes of the 1956 Melbourne Olympic Games, was founded in the early fifties. It still exists but has no Hungarian character or membership anymore. There were two so-called Hungarian Houses in the city, the centers of social life from the sixties through 1992. In 1986, the community erected the monument Gloria Victis, commemorating the events of 1956, in the courtyard of the San Francisco State Building across from City Hall. There are two churches serving the Hungarians of the area, with one regular Sunday service in Hungarian each. One of them is the Hungarian Catholic Mission, located in Portola Valley, next to a small monastery which, along with an attached high school, was founded by exiled Hungarian Benedictine friars in 1957. (The school today is in the management of the American mother order.) The other institution is the Free Hungarian Reformed Church of San Francisco and Vicinity in Redwood City, established in San Francisco in 1950. The current address of the churches is indicative of the recent demographic shifts in the area: now they are both based south of San Francisco, where the majority of the work force has concentrated since the early seventies, based on Silicon Valley employment opportunities. These two institutions play a pivotal role in ethnic, religious and social life and in language and culture maintenance (cf. Hofman 127; Kloss 1966), accommodating events related to national holidays, picnics, cultural events, and benefit dinners that support deserving charitable or educational-cultural causes in the Carpathian Basin. The official state holiday of Hungary, King Saint Stephen's Day, has been celebrated in the Golden Gate Park since 1959, and it is supported by the city's Golden Gate Park Band. An important place for language and culture maintenance is provided by the scout groups. Although an increasing number of heritage speaker youth choose English as their primary language of communication (as there are fewer and fewer heritage speakers who consider Hungarian their primary one), nevertheless, there are still two such groups in the Bay Area, and their language of instruction remains Hungarian. These represent an attempt to maintain Hungarian at some level, but it doesn't seem realistic to maintain it as the primary language. In the cultural domain, we find the Corvinus Cultural Association, the First California Hussar Regiment, the folk dance group Eszterlánc which turned 30 in 2007, the Circle of Hungarian Engineers and Scientists, and also a soccer team. The goals of the Szabadságharcos Szövetség (Hungarian Freedom Fighters Federation, Inc., San Francisco Chapter) are tradition maintenance and charity. There are no longer Hungarian stores or shops per se in the area, and the last Hungarian restaurant closed in 2005. The press is represented in California by a weekly newspaper, published in Los Angeles, the Amerikai Magyar Hirlap (Hungarian American Newspaper), introduced in 1989. (The first local weekly, Californiai Magyarság (California Hungarians), founded in 1922, existed until 2010.) A Bay Area Hungarian telephone and business directory was published in 1995 and 2004, and a next edition is also planned.

German presence in the United States has been significantly longer and quantitatively greater than that of Hungarians. Germans arrived in the San Francisco area around the time of the 1848 Gold Rush, and this city has historically been their West Coast center since. In the 20th century, a larger number of German speakers arrived in the US in the 1950s, mainly for economic reasons. Postwar Germany was characterized by lack of employment, partly because of the expulsion of about 5 million ethnic Germans from the former Eastern territories, and partly because of the ruined economy. After 1948, freedom of travel was granted to German citizens by the allied occupational authorities, and in the same year the US reopened its borders for German immigrants. Through 1960 about 750,000 left for overseas (Krohn 338). The US Census Bureau indicates about 90,000 Germans for the state of California, and about 18,000 for the San Francisco Bay Area, which is about 50 percent higher than the number of Hungarians.

The current stratification of the local community is adequately described by the statement of one of the former pastors of St. Matthews Lutheran Church in San Francisco (founded in 1895): "[there are] three 
Tóth, Gergely. "Bilingual Experience in the Hungarian and German Immigrant Communities of the San Francisco Bay Area." AHEA: E-journal of the American Hungarian Educators Association, Volume 5 (2012): http://ahea.net/e-journal/volume-5-2012

distinctive groups: those people that came in the 1950s and 1960s, and who make up the majority of [this] German-speaking congregation; professionals and businesspeople in their 50s, who are quite often married to native-born Americans; and those [called] yuppies in their 20s to 35, working for companies in the Silicon Valley" (<http://www.stmatthews-sf.org/images/pdf/history.pdf >).

The first documented organization in San Francisco was the Allgemeine Deutsche Unterstützungsgesellschaft (German General Benevolent Society) and its hospital, established January 7 , 1854. The German population of San Francisco formed benevolent societies and social-cultural associations early, among them Gesang-, Turn- and Schützenvereine (singing, gymnastics and shooting clubs). The main purpose of the latter groups was the maintenance of traditions associated with hunting and hiking. The attitude of these groups attracted the attention of the American population as well. As the article "Denkmale Deutscher Kultur" (sic), dated 1918, says, "in die nüchterne, puritanische Lebensauffassung des Amerikaners trugen sie den Idealismus der Deutschen" ("These enriched the simple, puritanical way of life of Americans by German idealism.” - My translation; California Staats Zeitung, January 30, 2003:10).

An outstanding role in the retention of German language and culture is played by the lodge-system of the Orden der Hermann Söhne (founded in 1840 in New York City), of which some of the informants of this survey are members. This network still exists and is represented countrywide, although the number of locations (13 in California in 2004 and 11 as of 2006) and membership have diminished sharply in the last decades. The San Francisco chapter formed in 1870, and soon 70 lodges were established across the state. Among other achievements, the organization introduced the German Day in San Francisco, still celebrated annually. It played a leading role in the erection of the Beethoven and the Goethe-Schiller monuments in Golden Gate Park, and as part of its cultural mission, it also formed a Hermann Sohn Dramatischer Verein (Der Hermann-Sohn, April 17, 2003:3).

Langley's 1890 Directory lists several German or German-speaking organizations. The names of the entities reflect the geographical origin of the immigrants, both with respect to discrete countries (Germany, Switzerland, or Austria), and to various regions within Germany itself. At the beginning of the $20^{\text {th }}$ century, four churches served the San Francisco community; of these, only St. Matthews still operates today, offering one German-language service on Sunday morning. On one Sunday each month, the service is bilingual German-English, another sign of demographic changes. There is a German Christian church, the Gemeinde Gottes (German Church of God) in San Jose, established recently. Present-time organizations include the Allgemeiner Deutscher Frauenhilfsverein (German General Relief Association for Women) and the United German American Societies of the East Bay and of San Francisco (UGAS) which ran a retirement home (the Oakland Altenheim) until recently. Current members of the UGAS are, besides the Bay Area chapters of Hermann Söhne, the German Language and Culture Club, the German School of the East Bay, the Oakland Turnverein, the Sacramento Turnverein (Gymnastics Club), the music and dance group Almenrausch Schuhplattler, the Oakländer Tänzer, the Oakland Männerchor, and the Richmond Chor. There are also a handful of German restaurants and specialty stores in the area. The Peter Buhrmann Radio Show presents a two-hour German language program with music, announcements, and real-time news directly from Germany every Sunday morning. The newer, English-language Radio Goethe, also endorsed by the local GoetheInstitut, caters to younger listeners; it airs the music of German, Austrian, and Swiss bands for one hour on Thursday evening. Readers have access to two German-language weekly newspapers, the California StaatsZeitung (California State Newspaper) and the recently launched Neue Presse (New Press). Both are published in the Los Angeles area but they feature a San Francisco section. Local publications are the monthly newsletter of the lodges, Der Hermann-Sohn, and the annually updated Das Buch. A Northern California Directory of German, Austrian and Swiss organizations, events and businesses, compiled by the UGAS.

The speakers of both the Hungarian and German speech communities are witnessing the gradual deconstruction and deterioration of their native language, especially across ensuing generations. Many community members try to resist assimilation, some accept it as unavoidable, but basically everyone supports integration. To be sure, in a melting pot society as the United States, this kind of language shift seems inevitable, in all immigrant groups, and regardless of their geographic location. One specific example of attempts to maintain a level of coordinate biculturalism and bilingualism is the linguistic behavior of the Hungarian scout groups (cf. Fishman, Hungarian Language Maintenance 18) that also function, with 
Tóth, Gergely. "Bilingual Experience in the Hungarian and German Immigrant Communities of the San Francisco Bay Area." AHEA: E-journal of the American Hungarian Educators Association, Volume 5 (2012): http://ahea.net/e-journal/volume-5-2012

somewhat different goals of course, as a substitute for the formerly relatively extensive network of ethnic Sunday schools. There were several such schools (apt examples of the "English plus" framework, which entails approaches and policies that encourage the use and maintenance of heritage languages, cf. Sollors 3) across various states until about the 1980's, mostly on the East Coast. Opposing trends such as the Internet, easier travel, a slight increase in heritage language enrollment, possibly brought about by Hungary's EUmembership, or by Germany's success in global economy, have helped a little, but not significantly. When natural settings of native language use disappear, the assimilation of younger speakers is faster. A slower assimilation seems to be true for students fortunate enough to spend some time in the country of their heritage, since these trips provide the opportunity to practice the heritage language in a natural environment. The Hungarian scouts' policy has been to teach children strictly in Hungarian, although the groups, in terms of using this language as the primary tool for communication, are divided along an active/passive line, with most of the young participants preferring to speaking English with their peers. This indicates a conflict between communicative and symbolic functions of the language, i.e., a growing gap between real/actual language use vs. the emotional importance attached to the language as a marker of identity (Oakes 3 ). The preference for English of the young bicultural speakers, whose majority belongs to an age segment that is strongly under peer pressure to give up their heritage language, signals convergence to the dominant American outgroup. This is also often associated with an over-communication of this dominant group's culture. Consequently, these educational institutions face a serious question regarding their ethnic identity maintenance. As one, not desired alternative, they could, as the number of incoming children reduces, dissolve. Or, as another option, they may switch over to English as the main instructional language. In the latter scenario, the groups would need to assign less importance to language as a component of ethnicity and compensate by other aspects, and a crucial source of group solidarity would in fact be absent. Of course, this change to English, even if gradual, would lead to an increasingly diffuse ethnic community, becoming less tightly organized and interactive, community focus, rule sharing and regularity would lag behind, and the assimilation process would accelerate. In any case, intermarriage today is prevalent, contributing to the further weakening of the children's heritage linguistic fluency and to member divergence from the core community. True, Alsatian is frequently mentioned as one relatively successful instance of identity retention after language loss or shift (Le Page and Tabouret-Keller 238), and one could think of the Irish as well, but whether ethnic identity can indeed survive the loss of the original language is doubtful. To be sure, although it is assumed that "this identity can, and does, survive the loss of the original group language" (Liebkind 144 , in the context of the Irish in Ireland), the scenario discussed in this paper is significantly different since it involves dislocated populations. The communities examined here are geographically far separated from their linguistic and cultural homeland, they lack compact, more or less homogenous neighborhoods, and the language sociology of their current living area, applying strong assimilative pressures, also favors the direction of shift to English. Consequently, many have doubts and are concerned that post-language-shift ethnic identity may eventually be limited, to quote one of the Hungarian community leaders, to "dining on gulyás, or celebrating the Oktoberfest and St. Patrick's Day." It seems reasonable to say that once the language, "the most important symbol of ethnic identity" (Liebkind 143) and a key to many cultural commodities, is gone, the speaker does not have access to written or spoken native cultural wealth anymore. Thus, even if many cultural aspects continue to be present after language loss, such as folk music, dance, cuisine, or visually enjoyable folk art, the overall cultural inventory at the community's disposal would be significantly impoverished. In addition, the loss of the common language that strengthens ethnic cohesion and acts as a link to heritage culture would also mean the loss of a powerful symbol. As the primary effect of symbols in general is the evocation of emotions, the disappearance of the shared language would also result in yet one less potential avenue of reconnection with a complete way of life in the sense of Fishman (1991). Nevertheless, the notion that native/heritage varieties will be lost by the third or fourth generation seems to be generally accepted (cf. Mattheier 49; Hinton 29), and most community members are aware of this. Their commitment therefore mainly concentrates on delaying this process.

At the same time, the virtues of bilingualism are also clear. The importance of the immigrants' heritage linguistic fluency becomes obvious in that it is not only a crucial factor in cultural access, but, as Charlotte Linde points out, competence in the language, serving as an ethnicity marker, is sometimes also necessary for full membership in a given group for other reasons, e.g., "to be able to tell jokes/stories that 
Tóth, Gergely. "Bilingual Experience in the Hungarian and German Immigrant Communities of the San Francisco Bay Area." AHEA: E-journal of the American Hungarian Educators Association, Volume 5 (2012): http://ahea.net/e-journal/volume-5-2012

are only adequate in one specific language" (Linde 334), or to address things that are part of institutional memory. My interviews also revealed that linguistic (and, consequently, cultural) vitality enhances the strength level of the whole group. In turn, as Richard Bourhis suggests, the group's vitality level is a key component of its ability to reward and sanction group loyalty, and, therefore, an attractive cultural atmosphere enhances member-identification with that group (Bourhis 133).

At the present time, the communities in focus are characterized by diglossia. Nevertheless, this needs to be further specified, since these diglossic situations differ from Charles Ferguson's 1959 definition which entails the complementary varieties used for intragroup purposes, and primarily in groups which are sole or majority population in an area. To be sure, English is used in public contexts (with the exception of ethnic events and church services), while Hungarian or German are mostly limited to private, informal constellations. However, the various domains in which these two latter linguistic varieties are employed are not absolutely discrete: the varieties (Hungarian vs. English and German vs. English) are not fully complementary, as they are sometimes used interchangeably, such as resorting to English even in ethnic environments. Further, English, the superposed variety, is used for purposes of communication with the outgroup, i.e., with members of the surrounding society, therefore "intragroup" is also to be understood as "intergroup." Moreover, in a classic diglossic situation, the participating languages have some kind of formal recognition, officially or historically. This is not valid in these cases since the languages in question (San Francisco Bay Area Hungarian and German, as opposed to, for instance, the linguistic situation in Luxemburg or the language of the Pennsylvania Amish) have no such official status or historical continuity.

The sociolinguistic questionnaire I distributed also addresses the problem of loyalty and attitude towards the native/heritage language and culture, and the involvement in ethnic institutions that foster these. Such inquiries help to illuminate various aspects of native language use in these communities. It is fascinating to see, for instance, how some extremely engaged and linguistically and culturally loyal speakers behave when it comes to combining their native language and English, in exploitation of their linguistic repertoire (cf. Gal 286). In the German cohort, one of the first generation speakers noted that he and his wife, who are from different dialectal regions of Germany, often resort to English because the dissimilarity of their native dialects poses comprehension difficulties. He also revealed that "we are more fluent if we quickly borrow an English word instead of thinking about the German equivalent." As examples, he cited the fairly technical expressions mortgage and bypass surgery, or the semantically loaded terms pattern or privacy. Similarly, when addressing administrative, technical, medical, financial, or political topics, a speaker of the Hungarian group and her husband would code-switch to English and use it as a superposed variety in Ferguson's sense, resembling a true diglossic situation occurring at the micro-level of the family (Ferguson 326). Also, all speakers - not just my questionnaire subjects - of the two investigated communities are bilinguals "par excellence" (cf. Hymes 38). Subtractive bilingualism is the norm, since the majority of the children do not become fully competent in the mother tongue. Even if receptional skills are retained, productional skills diminish.

As for my survey, the youngest informant in the Hungarian cohort is 18 years old and the oldest one is $\mathbf{8 3}$. The overall group age average is $\mathbf{5 0 . 1 5}$ years. There are thirteen female and seven male interviewees. The average length of residence in the United States is 41.1 years. Six of the eight first generation interviewees have college or university degrees, six out of nine in the second generation, and one out of three in the third generation. One second-generation speaker is a college student. In this group there is one first-generation speaker who works with her native language on a daily basis. In the first generation, two speakers answered the question about loyalty to the native language and culture with "no"; so did two subjects in the second generation. The three third-generational informants all confirmed positive attitude and the importance of passing on the heritage language and culture. Five out of eight first- generation speakers are involved in some Hungarian cultural, linguistic or social organization, or church. The corresponding ratios in the second generation are 4:9, and 2:3 in the third. Four members of the first generation read in Hungarian regularly, one does so rarely, and three answered with "no". In the second generation only one person selected "yes", two chose "rarely", and six of them do not read regularly in Hungarian. One thirdgenerational speaker still reads in Hungarian rarely, the other two do not. In the first generation, four informants speak Hungarian in their homes fairly regularly, and another four checked "no". In the second generation, the yes/no ratio is three vs. six, while two third-generational speakers answered with "yes". Two 
Tóth, Gergely. "Bilingual Experience in the Hungarian and German Immigrant Communities of the San Francisco Bay Area." AHEA: E-journal of the American Hungarian Educators Association, Volume 5 (2012): http://ahea.net/e-journal/volume-5-2012

speakers do not maintain contacts in the Carpathian Basin; this number is five in the second, and two in the third generation.

The age of German interlocutors spans from 18 to 88 years, and the group's average age is 47.5 years. The gender distribution shows 11 female and nine male subjects. The age at which the first-generation speakers moved from their homeland ranges from 17 years to 28 years. The average number of years spent in the United States is 37.1. The first-generation informant set includes two speakers with college or university degrees. In the second generation, we find four students and three college graduates, while in the third generation there are two retirees and one college graduate. The only non-first-generational informant who has had tangible formal German language education is a third-generation interviewee. There are two speakers, both from the first generation, whose profession entails regular encounters with the German language.

Answering the questions about loyalty and attitude, and the transmission of native language and culture to future generations, only two second-generation informants showed a lack of interest. Six informants in the first generation, none in the second, and two in the third indicated active or regular participation in German organizations. Six speakers of the first generation read in German on a regular basis, two of them "rarely". In the successive generations, no one answered with "yes"; five second-generational subjects read in German rarely, and so do all three in the third generation. The information about interim use of the language, i.e., regular or semi-regular occurrence of German in the home show that five speakers in the first generation use the native language regularly, while two of them selected "no". In the second generation, four informants use German at home at various frequencies, while this figure is zero in the third generation. Regarding maintenance of contacts, "yes" was the answer of all eight first-generational speakers, of six second-generation informants, and none in the third generation.

The limits of this paper do not allow an in-depth account of the contact linguistic material, gained from the 40 questionnaires. (For a complete inventory of linguistic and sociolinguistic findings, both qualitative and quantitative, error frequencies, examples of how the two embedded languages absorb the impact of the matrix language differently, and detailed biographical data see Tóth 2007.) However, some general contrastive statements may be helpful in illustrating the gradual "disintegration or attrition" of the linguistic structures of the two examined embedded languages, eventually leading to language loss, and highlighting "the creation and dissolution of language grammars" (Seliger - Vago 3, and Seliger 228, resp.).

The survey shows that the native or heritage linguistic versions of the interviewed speakers become less stable over time. The fact that these informants live in an assimilative contact linguistic situation reflects on their language, regarding both the languages' grammatical system and the subjects' sociolinguistic behavior. Generally, but particularly in successive generations, an overall reduction of morphological complexity occurs, resulting in a more analytical linguistic structure. Grammatical features that seem most vulnerable in this respect are multiple-case systems and paradigms with a large amount of allomorphic variation, such as conjugation, grammatical tense and gender, or prefix systems. Indeed, the current data contain a high number of case marking irregularities, case syncretism and demise, difficulties associated with proper tense, mood, number and gender marking, modal verb and conjunction use, verb conjugation (including the loss of ability to keep subjective and objective paradigms of Hungarian and strong and weak paradigms of German apart), and possessive relations. The performance and the morphologically and syntactically severely affected heritage linguistic inventory of some of the speakers seem to point in a different direction than what Dorian calls language death "with its morphological boots on" (1978:608). These different scenarios indicate that language loss can take different paths and follow different dynamics: in her quoted case study, grammar seemed to stick around longer, while in my case, the speakers seem to lose grammar relatively early. Such consultants display a high number of lexical items in isolation, i.e., verbal and nominal stems without appropriate affixation. Other typical tendencies — at least partly interference-conditioned — include calquing, the weakening of idiomatic competence, lexical and structural borrowing (such as overt personal and possessive pronouns in Hungarian), and hardship in producing prescribed word order. 
Tóth, Gergely. "Bilingual Experience in the Hungarian and German Immigrant Communities of the San Francisco Bay Area." AHEA: E-journal of the American Hungarian Educators Association, Volume 5 (2012): http://ahea.net/e-journal/volume-5-2012

The linguistic and sociolinguistic results and descriptions and cross-cultural comparisons presented above shall contribute to a better understanding of contact linguistic tendencies occurring in immigrant settings in general and in the San Francisco Bay Area in particular. They also make clear that language and culture maintenance efforts are honorable, and they indeed manage to slow down the assimilation process, but under the given circumstances, eventual language loss seems inevitable.

\section{Works Cited}

Bourhis, Richard Y. 1979. "Language in Ethnic Interaction: a Social Psychological Perspective." Language and Ethnic Relations. Ed. Howard Giles and Bernard Saint-Jacques. Oxford: Pergamon. 117-42.

California Staats-Zeitung. A Weekly German Language Newspaper. Select issues. Los Angeles, California.

Dorian, Nancy C. 1978. "The Fate of Morphological Complexity in Language Death: Evidence from East Sutherland Gaelic." Language 54: 590-609.

Ferguson, Charles A. 1959. "Diglossia." Word 15: 325-40.

Fishman, Joshua. 1991. Reversing Language Shift: Theoretical and Empirical Foundations of Assistance to Threatened Languages. Philadelphia: Multilingual Matters.

Gal, Susan. 1988. "Linguistic Repertoire." HSK Soziolinguistik. Ein internationales Handbuch zur Wissenschaft von Sprache und Gesellschaft. Ed. Ulrich Ammon, Norbert Dittmar and Klaus J. Mattheier. Berlin/New York: de Gruyter. 286-93.

Der Hermann-Sohn. Official Publication of the Order of Hermanns Sons and Sisters of the State of California (incorporated May 22, 1923). Select issues. Published monthly. H. Nitzsche, ed. San Lorenzo, California (after 2005: Alfred Langen, ed.).

Hinton, Leanne. 1999. "Trading Tongues: Loss of Heritage Languages in the United States.” English Today 60, Vol. 15/4: 21-30.

Hofman, John E. 1966. "Mother Tongue Retentiveness in Ethnic Parishes." Language Loyalty in the United States: the Maintenance and Perpetuation of non-English Mother Tongues by American Ethnic and Religious Groups. Ed. Joshua Fishman. The Hague: Mouton. 127-55.

Hymes, Dell. 1974. "Models of Interaction of Language and Social Life." Directions in Sociolinguistics. Ed. John Gumperz and Dell Hymes. New York: Holt, Rinehart \& Winston. 35-71.

Kloss, Heinz. 1966. "German-American Language Maintenance Efforts." Language Loyalty in the United States. Ed. Joshua Fishman. The Hague: Mouton. 206-52.

Krohn, Heinrich. 1992. Und warum habt ihr denn Deutschland verlassen? 300 Jahre Auswanderung nach Amerika. Bergisch Gladbach: Gustav Lübbe Verlag.

Langley's San Francisco, California General and Business Directory for 1890. San Francisco: Painter \& Co., 1890

Langman, Juliet. 1997. 'Expressing Identity in a Changing Society: Hungarian Youth in Slovakia.' Beyond Borders: Remaking Cultural Identity in the New East and Central Europe. Ed. László Kürti and Juliet Langman. Boulder: Westview. 111-32.

Le Page, Robert B. - Andrée Tabouret-Keller. 1985. Acts of Identity: Creole Based Approaches to Language and Ethnicity. Cambridge: Cambridge UP.

Liebkind, Karmela. 1999. "Social psychology." Handbook of Language and Ethnic Identity. Ed. Joshua Fishman. Oxford: Oxford UP. 140-51.

Linde, Charlotte. 1996. "Whose Story is This?: Point of View Variation and Group Identity in Oral Narrative." Sociolinguistic Variation. Data, Theory, and Analysis. Selected Papers from NWAV 23 at Stanford. Ed. Jennifer Arnold, Renee Blake, Brad Davidson, Scott Schwenter and Julie Solomon. Stanford: CSLI Publications. 333-45.

Lüdi, Georges. 1996. "Multilingualism Through Migration: A Comparison of Internal and External Migrant Communities in Switzerland." Contrastive Sociolinguistics. Ed. Marlis Hellinger and Ulrich Ammon. Berlin/New York: de Gruyter. 103-33.

Mattheier, Klaus J. 1993. "Sprachinselsoziolinguistik: Beobachtungen und Überlegungen and deustchsprachigen Sprachinseln.” The German Language in America 1683-1991. Ed. Joseph C. Salmons. Madison: The U of Wisconsin P. 38-61. 
Nielsen, Nils. (Year not indicated). "A Corner of San Francisco with a German Past". <http://www.stmatthews-sf.org/images/pdf/history.pdf >.

Oakes, Leigh. 2001. Language and National Identity. Comparing France and Sweden. Amsterdam/Philadelphia: John Benjamins.

Paul, Hermann. 1909. Prinzipien der Sprachgeschichte. Freiburg: Halle/Saale.

Rauch, Irmengard et al. 1988. "San Francisco Bay Area German: A Pilot Study." Monatshefte 80, No. 1: $94-$ 102.

Schuchardt, Hugo. 1883. “Über das Malaiospanische der Philippinen.” Sitzungsberichte der Wiener Akademie 105, 1: 111-50.

Seliger, Herbert W. 1991. "Language Attrition, Reduced Redundancy, and Creativity." First Language Attrition. Ed. Herbert W. Seliger and Robert M. Vago. Cambridge: Cambridge UP. 227-40.

Seliger, Herbert W. and Robert M. Vago, eds. 1991. First Language Attrition. Cambridge: Cambridge UP.

Sollors, Werner. 1998. "Introduction: After the Culture Wars; or, From "English Only" to "English Plus". Multilingual America. Transnationalism, Ethnicity, and the Languages of American Literature. Ed. Werner Sollors. New York: New York UP. 1-16.

Tóth, Gergely. 2007. Linguistic Interference and First Language Attrition. German and Hungarian in the San Francisco Bay Area. New York/Bern/Oxford: Peter Lang.

Weinreich, Uriel. 1953. Languages in Contact. The Hague: Mouton. 